\title{
Expeditious Entry to Novel 2-Methylene-2,3-dihydrofuro[3,2-c] chromen-2-ones from 6-Chloro-4-hydroxychromen-2-one and Propargylic Alcohols
}

\author{
Noel Nebra, Alba E. Díaz-Álvarez, Josefina Díez and Victorio Cadierno * \\ Departamento de Química Orgánica e Inorgánica, IUQOEM-CSIC, Facultad de Química, Universidad \\ de Oviedo, E-33071 Oviedo, Spain
}

* Author to whom correspondence should be addressed; E-Mail: vcm@uniovi.es;

Tel.: +34-985-103-453; Fax: +34-985-103-446.

Received: 14 July 2011; in revised form: 27 July 2011 / Accepted: 28 July 2011 /

Published: 2 August 2011

\begin{abstract}
A catalytic system consisting of the ruthenium(II) complex $\left[\mathrm{Ru}\left(\eta^{3}-2\right.\right.$ $\left.\left.\mathrm{C}_{3} \mathrm{H}_{4} \mathrm{Me}\right)(\mathrm{CO})(\mathrm{dppf})\right]\left[\mathrm{SbF}_{6}\right](\mathrm{dppf}=1,1$ '-bis(diphenylphosphino)ferrocene) and trifluoroacetic acid has been used to promote the coupling of secondary propargylic alcohols with 6-chloro-4-hydroxychromen-2-one. The reactions afforded unusual 2-methylene-2,3dihydrofuro[3,2-c] chromen-2-ones in good yields.
\end{abstract}

Keywords: chromen-2-ones; furochromen-2-ones; propargylic alcohols; ruthenium catalysts; propargylation; cycloisomerization

\section{Introduction}

Chromen-2-ones (coumarins) constitute an important family of heterocyclic compounds of natural origin which have attracted considerable attention for many years due to their versatile applications [1-4]. Among them, furochromen-2-ones (furocoumarins), tricyclic systems in which a furan ring is fused to the chromen-2-one unit, are of particular interest since they exhibit potent biological and pharmacological activity [5-8]. Although several methods of synthesis are presently known [7,8], new approaches for the rapid and selective construction of furochromen-2-one scaffolds are still highly desirable. In this context, recent efforts by different groups have been focused in the one-pot synthesis of furo[3,2-c]chromen-2-ones (Figure 1) from readily available starting materials, with successful examples 
including CAN-mediated cycloaddition of 4-hydroxychromen-2-one with terminal alkynes $[9,10]$, rhodium(II)-catalyzed heterocyclization of 3-diazo-2,4-chromenediones with terminal alkynes [11,12], cascade addition/cyclization/oxidation of 3-alkynyl-chromones [13,14], Sonogashira-acetylide coupling/ demethylation/cyclization of 3-iodo-4-methoxychromen-2-ones [15,16] and alkynylation/ hydroalkoxylation of 3-bromo-4-acetoxychromen-2-ones [17].

Figure 1. The furo[3,2-c]chromen-2-one skeleton.<smiles>O=c1oc2ccccc2c2occc12</smiles>

In the course of our studies focused on the application of ruthenium catalysts for the construction of furan- and pyrrole-ring frameworks [18-25], we disclosed a straightforward approach of tetrasubstituted furans from readily accessible secondary propargylic alcohols and 1,3-dicarbonyl compounds (Scheme 1) [18]. The process, which proceeds in a one-pot manner, involves the initial trifluoroacetic acid-promoted propargylation of the 1,3-dicarbonyl compound, and subsequent cycloisomerization of the resulting $\gamma$-ketoalkyne A (5-exo cyclization + aromatization) catalyzed by the 16-electron allyl-ruthenium(II) complex $\left[\mathrm{Ru}\left(\eta^{3}-2-\mathrm{C}_{3} \mathrm{H}_{4} \mathrm{Me}\right)(\mathrm{CO})(\mathrm{dppf})\right]\left[\mathrm{SbF}_{6}\right]$ (1).

Scheme 1. Direct synthesis of furans from alkynols and 1,3-dicarbonyl compounds.

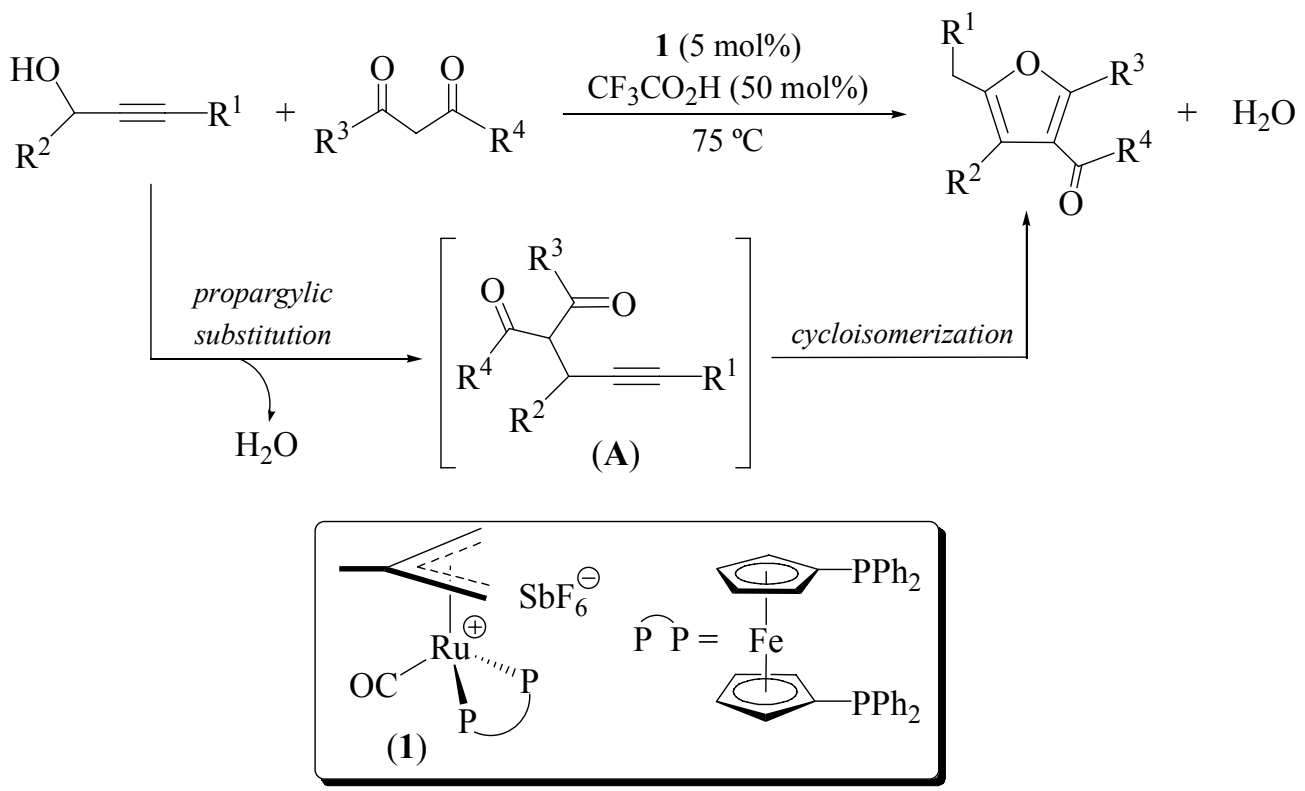

By applying this synthetic route a large variety of furans containing carbonyl functionalities on the aromatic ring, could be prepared in good yields starting from both terminal and internal secondary alkynols, and $\beta$-diketones or $\beta$-keto esters $[18,21]$. In addition, we also demonstrated that furo[3,2$c$ chromen-2-ones are also accessible by this route using 4-hydroxychromen-2-one as substrate, representing an appealing one-pot method of synthesis for this type of heterocycles [21]. Related work by Zhou and co-workers also confirmed the utility of this propargylation-cycloisomerization sequence for the construction of furochromen-2-one skeletons [26]. 
Following with these studies, herein we would like to communicate that related $\mathrm{C}-\mathrm{C}$ coupling processes involving 6-chloro-4-hydroxychromen-2-one and terminal propargylic alcohols $\mathrm{HC} \equiv \mathrm{CC}(\mathrm{OH}) \mathrm{HR}$ result in the selective formation of the 2-methylene-2,3-dihydrofuro[3,2-c]chromen2-one derivatives 4 (Figure 2), instead of the expected 8-chloro-substituted furo[3,2-c]chromen-2-ones $\mathbf{5}$, due to the reluctance of the former to undergo aromatization of the five-membered ring.

Figure 2. Structures of compounds 4 and 5.<smiles>[R]C1C(=C)Oc2c1c(=O)oc1ccc(Cl)cc21</smiles>

(4)<smiles>[R]c1c(C)oc2c1c(=O)oc1ccc(Cl)cc12</smiles>

(5)

\section{Results and Discussion}

Initially, the coupling of the secondary propargylic alcohol 1-(4-methoxyphenyl)-2-propyn-1-ol (2a) with 6-chloro-4-hydroxychromen-2-one (3) was investigated under the same reaction conditions previously employed by us in the synthesis of furo[3,2-c]chromen-2-one derivatives starting from 4-hydroxychromen-2-one [21], that is, heating a THF solution of both reactants (equimolar mixture) at $75{ }^{\circ} \mathrm{C}$ in the presence of $50 \mathrm{~mol} \%$ of trifluoroacetic acid and $5 \mathrm{~mol} \%$ of the allyl-ruthenium(II) complex 1 (Scheme 2). Almost complete disappearance of the starting materials, accompanied by the selective formation of a single reaction product $\mathbf{4 a}$, was observed by GC after 8 hours of heating.

Scheme 2. Catalytic synthesis of compound $\mathbf{4 a}$ under classical thermal conditions.

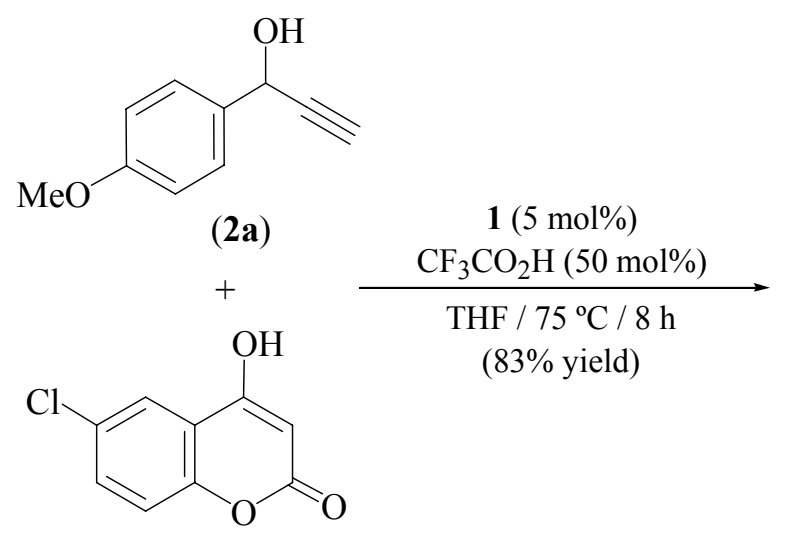<smiles>C=C1Oc2c(c(=O)oc3ccc(Cl)cc23)C1c1ccc(OC)cc1</smiles>

(4a)

(3)

Appropriate chromatographic workup allowed the isolation of $\mathbf{4 a}$ as a crystalline yellow solid in 83\% yield. NMR spectroscopic data obtained for 4 a clearly revealed the selective formation of a 2-methylene-2,3-dihydrofuran unit, instead of the expected aromatic 2-methylfuran one (details are given in the Experimental), a fact that was unambiguously confirmed by means of a single-crystal X-ray diffraction study (an ORTEP view of the molecule is shown in Figure 3; selected bonding parameters are listed in Table 2). The bond distance C10-C11 (1.321(3) $\AA$ ) showed the expected value for a $\mathrm{C}=\mathrm{C}$ bond, while that observed for $\mathrm{C} 10-\mathrm{C} 12$ (1.523(3) $\AA$ ) falls within the expected range for a $\mathrm{C}\left(\mathrm{sp}^{2}\right)-\mathrm{C}\left(\mathrm{sp}^{3}\right)$ single bond. 
Figure 3. ORTEP-type view of the structure of compound 4a showing the crystallographic labelling scheme. Thermal ellipsoids are drawn at the $20 \%$ probability level.

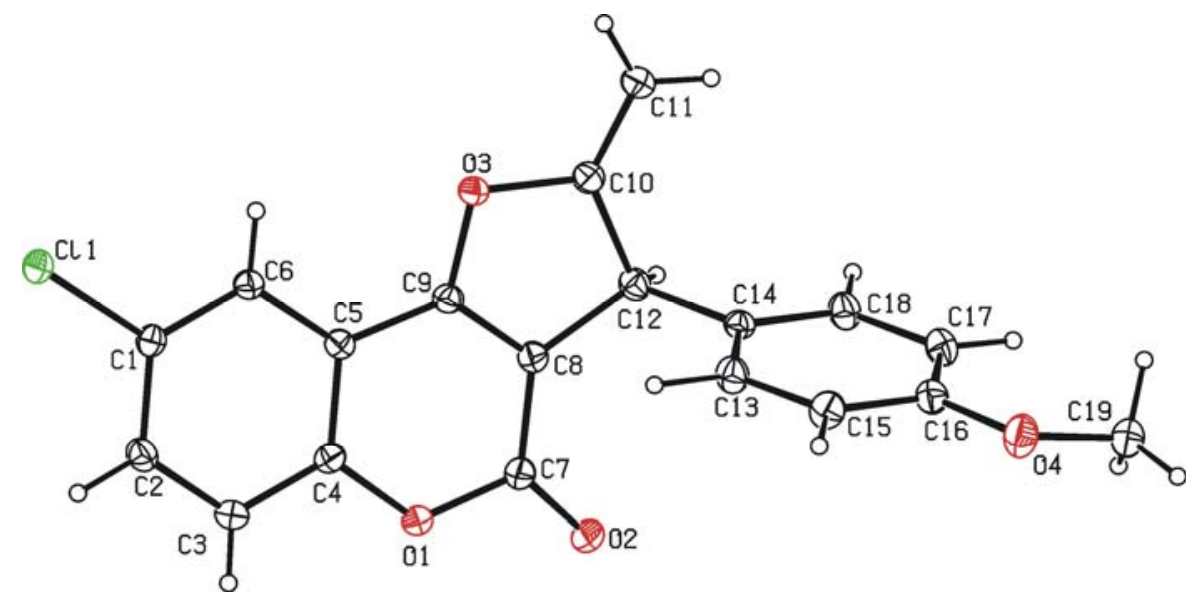

Table 2. Selected bond distances $(\AA)$ and angles $\left(^{\circ}\right)$ for compound $\mathbf{4 a}$.

\begin{tabular}{|l|l|}
\hline \multicolumn{2}{|c|}{ Distances } \\
\hline C8-C9 & $1.338(3)$ \\
C9-O3 & $1.360(2)$ \\
O3-C10 & $1.417(2)$ \\
C10-C11 & $1.321(3)$ \\
C10-C12 & $1.523(3)$ \\
C12-C8 & $1.507(3)$ \\
C7-O1 & $1.393(3)$ \\
C7-O2 & $1.211(3)$ \\
C1-C11 & $1.738(2)$ \\
\hline \multicolumn{2}{|c|}{ Angles } \\
\hline C8-C9-O3 & $114.13(18)$ \\
C9-O3-C10 & $106.39(16)$ \\
O3-C10-C11 & $118.8(2)$ \\
C11-C10-C12 & $131.1(2)$ \\
O3-C10-C12 & $110.07(16)$ \\
C10-C12-C8 & $99.46(17)$ \\
C12-C8-C9 & $109.77(18)$ \\
\hline
\end{tabular}

The use of microwave (MW) irradiation represents a convenient alternative to the conventional thermal heating in organic synthesis since a more effective energy transfer to the system takes place, thus shortening considerably the reaction times and improving in many cases the product yields [27-29]. Accordingly, we have found that, performing the same coupling reaction of alkynol 2a with $\mathbf{3}$ under controlled microwave heating at $75{ }^{\circ} \mathrm{C}$, selective and almost quantitative formation of 2-methylene2,3-dihydrofuro[3,2-c]chromen-2-one (4a, 99\% GC-yield; 89\% isolated yield) takes place after only $10 \mathrm{~min}$. As shown in Scheme 3, the process is general since the related heterocycles $\mathbf{4 b}-\mathbf{d}$ could also be synthesized in good yields (77\%-92\%) by reacting 3 with the secondary propargylic alcohols 1-(2methoxyphenyl)-2-propyn-1-ol (2b), 1-(1-naphthyl)-2-propyn-1-ol (2c) and 1-(2-thienyl)-2-propyn-1ol (2d) under the same MW conditions. 
Scheme 3. Catalytic synthesis of compound 4a-d under MW-irradiation.

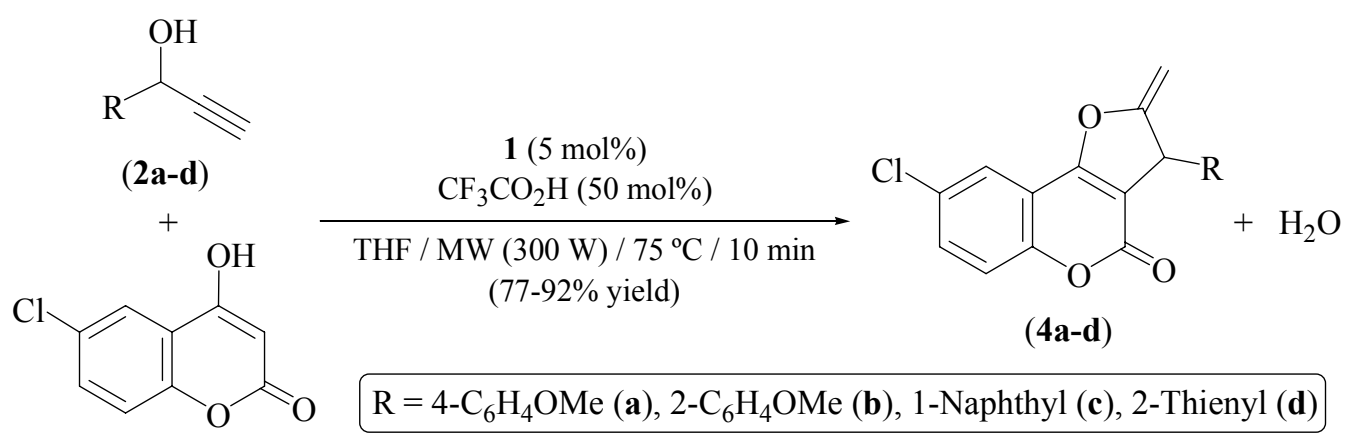

(3)

The presence of a 2-methylene-2,3-dihydrofuran moiety in the structure of these compounds was readily identified by the appearance of a high-field $\mathrm{CH}$ carbon resonance at 43-49 ppm (CHR unit) and a $\mathrm{CH}_{2}$ signal at $c a .92 \mathrm{ppm}$, typical of a terminal olefinic $=\mathrm{CH}_{2}$ unit, in their ${ }^{13} \mathrm{C}\left\{{ }^{1} \mathrm{H}\right\}$-NMR spectra (DEPT experiments). Characteristic ${ }^{1} \mathrm{H}-\mathrm{NMR}$ peaks for these units were also observed at 4.5-5.5 ppm (details can be found in the Experimental).

At this point, it is worthy of note that occurrence of 2-methylene-2,3-dihydrofuro[3,2-c]chromen-2ones has been scarcely documented in the literature [30-35], with most of the know examples being disubstituted at the C-3 position of the 2-methylene-2,3-dihydrofuran ring which prevents their tautomerization into the corresponding 2-methyl-furo[3,2-c]chromen-2-ones. In this sense, the reluctance shown by compounds $\mathbf{4 a - d}$ to aromatize under the acidic conditions employed merits to be highlighted. In fact, only in the case of $\mathbf{4 b}$ such aromatization process could be observed after prolonged MW irradiation $(3 \mathrm{~h})$ of the reaction mixture at $100{ }^{\circ} \mathrm{C}$. Under this conditions, the novel 8-chloro-substituted furo[3,2-c] chromen-2-one $\mathbf{5 b}$ could be synthesized with an acceptable $63 \%$ yield and fully characterized (Scheme 4).

Scheme 4. Synthesis of the furo[3,2-c]chromen-2-one $\mathbf{5 b}$.

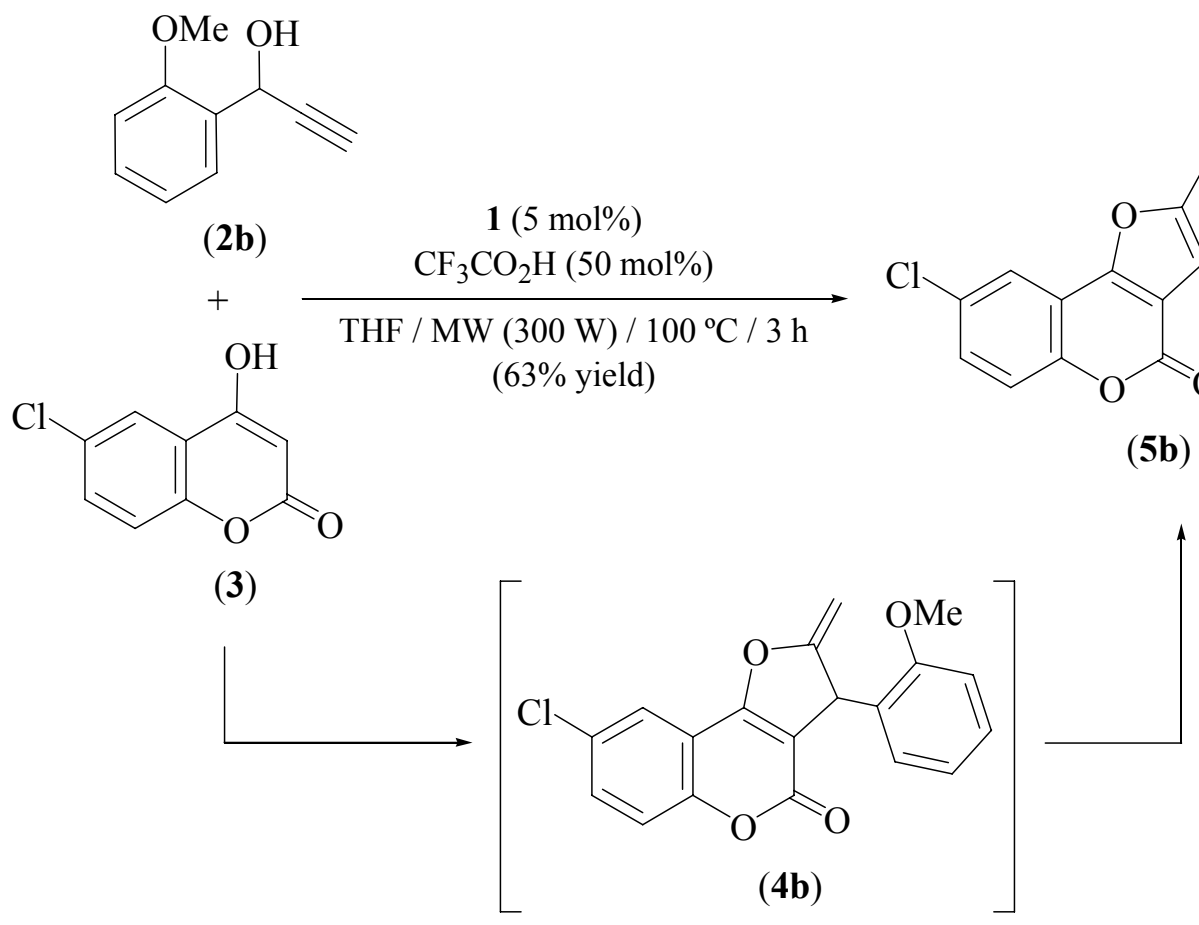




\section{Experimental}

\subsection{General}

Solvents were dried by standard methods and distilled under nitrogen before use. The complex $\left[\mathrm{Ru}\left(\eta^{3}-2-\mathrm{C}_{3} \mathrm{H}_{4} \mathrm{Me}\right)(\mathrm{CO})(\mathrm{dppf})\right]\left[\mathrm{SbF}_{6}\right](\mathbf{1})$ [36] and propargylic alcohols 2a-d [37] were prepared by following the methods reported in the literature. Flash chromatography was performed using Merck silica gel 60 (230-400 mesh). Melting points were determined in a Gallenkamp apparatus and are uncorrected. Infrared spectra were recorded on a Perkin-Elmer 1720-XFT spectrometer. NMR spectra were recorded on a Bruker DPX-300 instrument at $300 \mathrm{MHz}\left({ }^{1} \mathrm{H}\right)$ or $75.4 \mathrm{MHz}\left({ }^{13} \mathrm{C}\right)$. The chemical shift values $(\delta)$ are given in parts per million and are referred to the residual peak of the deuterated solvent used $\left(\mathrm{CDCl}_{3}\right)$. High-resolution mass spectra (HRMS) were provided by the Mass Spectrometry Service of the Instituto de Investigaciones Químicas (IIQ-CSIC, Seville). CCDC 831021 contains the supplementary crystallographic data for this paper. These data can be obtained free of charge from The Cambridge Crystallographic Data Centre via www.ccdc.cam.ac.uk/data_request/cif.

\subsection{Synthesis of the 8-chloro-2-methylene-2,3-dihydrofuro[3,2-c]chromen-2-ones 4a-d}

Under a nitrogen atmosphere, a pressure-resistant septum-sealed glass vial was charged with the corresponding propargylic alcohol 2a-d (1 mmol), 6-chloro-4-hydroxychromen-2-one (3) (0.197 g, $1 \mathrm{mmol})$, THF $(0.5 \mathrm{~mL}),\left[\mathrm{Ru}\left(\eta^{3}-2-\mathrm{C}_{3} \mathrm{H}_{4} \mathrm{Me}\right)(\mathrm{CO})(\mathrm{dppf})\right]\left[\mathrm{SbF}_{6}\right]$ (1) (0.049 g, $\left.0.05 \mathrm{mmol}\right), \mathrm{CF}_{3} \mathrm{CO}_{2} \mathrm{H}$ ( $37 \mu \mathrm{L}, 0.5 \mathrm{mmol}$ ) and a magnetic stirring bar. The vial was then placed inside the cavity of a CEM Discover ${ }^{\circledR}$ S-Class microwave synthesizer and power was held at $300 \mathrm{~W}$ until the desired temperature was reached $\left(75{ }^{\circ} \mathrm{C}\right)$. Microwave power was automatically regulated for the remainder of the experiment (10 $\mathrm{min})$ to maintain the temperature (monitored by a built-in infrared sensor). Then, the vial was cooled to room temperature, the volatiles removed under vacuum, and the residue purified by flash chromatography (silica gel) using a mixture EtOAc/hexanes (1:20) as eluent. Characterization data for the novel 8-chloro-2-methylene-2,3-dihydrofuro[3,2-c]chromen-2-ones 4a-d are as follows:

8-Chloro-3-(4-methoxyphenyl)-2-methylene-2,3-dihydrofuro[3,2-c]chromen-2-one (4a). Yellow solid (0.303 g, 89\%); m.p. $125-127{ }^{\circ} \mathrm{C}$; IR (Nujol) $v=1721(\mathrm{C}=\mathrm{O}) \mathrm{cm}^{-1} ;{ }^{1} \mathrm{H}-\mathrm{NMR}\left(\mathrm{CDCl}_{3}\right) \delta=3.78$ (s, $3 \mathrm{H}), 4.52(\mathrm{dd}, 1 \mathrm{H}, J=3.4$ and $2.8 \mathrm{~Hz}), 5.11(\mathrm{~m}, 2 \mathrm{H}), 6.87(\mathrm{~d}, 2 \mathrm{H}, J=8.5 \mathrm{~Hz}), 7.23(\mathrm{~d}, 2 \mathrm{H}, J=8.5 \mathrm{~Hz})$, $7.32(\mathrm{~d}, 1 \mathrm{H}, J=8.8 \mathrm{~Hz}), 7.53(\mathrm{dd}, 1 \mathrm{H}, J=8.8$ and $2.2 \mathrm{~Hz}), 7.75(\mathrm{~d}, 1 \mathrm{H}, J=2.2 \mathrm{~Hz}) \mathrm{ppm} ;{ }^{13} \mathrm{C}-\mathrm{NMR}$ $\left(\mathrm{CDCl}_{3}\right) \delta=47.7,55.2,91.7,107.4,112.5,114.2,118.5,122.2,128.8,129.6,131.2,132.7,153.5$, 159.1, 157.8, 162.9, 164.8 ppm; HRMS (EI) $m / z=340.0501, \mathrm{C}_{19} \mathrm{H}_{13} \mathrm{O}_{4} \mathrm{Cl}$ requires 340.0502 .

8-Chloro-3-(2-methoxyphenyl)-2-methylene-2,3-dihydrofuro[3,2-c]chromen-2-one (4b). Yellow solid (0.262 g, 77\%); m.p. 122-124 ${ }^{\circ} \mathrm{C}$; IR (Nujol) $v=1748(\mathrm{C}=\mathrm{O}) \mathrm{cm}^{-1} ;{ }^{1} \mathrm{H}-\mathrm{NMR}\left(\mathrm{CDCl}_{3}\right) \delta=3.79(\mathrm{~s}, 3 \mathrm{H})$, $4.55(\mathrm{dd}, 1 \mathrm{H}, J=3.0$ and $2.5 \mathrm{~Hz}), 5.12(\mathrm{~m}, 2 \mathrm{H}), 6.82-6.91(\mathrm{~m}, 3 \mathrm{H}), 7.25(\mathrm{~m}, 1 \mathrm{H}), 7.34(\mathrm{~d}, 1 \mathrm{H}, J=8.9 \mathrm{~Hz})$, $7.55(\mathrm{dd}, 1 \mathrm{H}, J=8.9$ and $2.4 \mathrm{~Hz}), 7.76(\mathrm{~d}, 1 \mathrm{H}, J=2.2 \mathrm{~Hz}) \mathrm{ppm} ;{ }^{13} \mathrm{C}-\mathrm{NMR}\left(\mathrm{CDCl}_{3}\right) \delta=48.5,55.3$, 92.1, 107.2, 112.6, 113.0, 113.8, 118.6, 120.1, 122.3, 129.8, 130.0, 132.9, 140.7, 153.6, 157.9, 160.0, 163.4, 164.3 ppm; HRMS (EI) $m / z=340.0513, \mathrm{C}_{19} \mathrm{H}_{13} \mathrm{O}_{4} \mathrm{Cl}$ requires 340.0502 . 
8-Chloro-3-(1-naphthyl)-2-methylene-2,3-dihydrofuro[3,2-c]chromen-2-one (4c). Yellow solid (0.331 g, 92\%); m.p. 140-142 ${ }^{\circ} \mathrm{C}$; IR (Nujol) $v=1719(\mathrm{C}=\mathrm{O}) \mathrm{cm}^{-1} ;{ }^{1} \mathrm{H}-\mathrm{NMR}\left(\mathrm{CDCl}_{3}\right) \delta=4.55(\mathrm{dd}, 1 \mathrm{H}, J=3.3$ and $2.5 \mathrm{~Hz}), 5.15(\mathrm{dd}, 1 \mathrm{H}, J=3.3$ and $2.5 \mathrm{~Hz}), 5.33(\mathrm{dd}, 1 \mathrm{H}, J=3.3$ and $3.3 \mathrm{~Hz}), 7.33-7.49(\mathrm{~m}, 5 \mathrm{H})$, 7.81-7.85 (m, 5H) ppm; ${ }^{13} \mathrm{C}-\mathrm{NMR}\left(\mathrm{CDCl}_{3}\right) \delta=48.8,92.3,107.3,112.6,118.7,122.4,125.3,126.2$, $126.4,127.0,127.7,127.9,129.0,129.8,132.9,133.0,133.4,136.5,153.6,157.9,163.4,164.5$ ppm; HRMS (EI) $m / z=360.0557, \mathrm{C}_{22} \mathrm{H}_{13} \mathrm{O}_{3} \mathrm{Cl}$ requires 360.0553 .

8-Chloro-3-(2-thienyl)-2-methylene-2,3-dihydrofuro[3,2-c]chromen-2-one (4d). Orange solid (0.253 g, 80\%); m.p. $131-133{ }^{\circ} \mathrm{C}$; IR (Nujol) $v=1733(\mathrm{C}=\mathrm{O}) \mathrm{cm}^{-1}$; ${ }^{1} \mathrm{H}-\mathrm{NMR}\left(\mathrm{CDCl}_{3}\right) \delta=4.72(\mathrm{dd}, 1 \mathrm{H}, J=3.5$ and $2.4 \mathrm{~Hz}), 5.18(\mathrm{dd}, 1 \mathrm{H}, J=3.5$ and $2.7 \mathrm{~Hz}), 5.48(\mathrm{dd}, 1 \mathrm{H}, J=2.7$ and $2.4 \mathrm{~Hz}), 6.98(\mathrm{dd}, 1 \mathrm{H}, J=5.2$ and $3.6 \mathrm{~Hz}), 7.12(\mathrm{dd}, 1 \mathrm{H}, J=3.6$ and $1.1 \mathrm{~Hz}), 7.25(\mathrm{dd}, 1 \mathrm{H}, J=5.2$ and $1.1 \mathrm{~Hz}), 7.35(\mathrm{~d}, 1 \mathrm{H}, J=9.0 \mathrm{~Hz})$, $7.56(\mathrm{dd}, 1 \mathrm{H}, J=9.0$ and $2.5 \mathrm{~Hz}), 7.75(\mathrm{~d}, 1 \mathrm{H}, J=2.5 \mathrm{~Hz}) \mathrm{ppm} ;{ }^{13} \mathrm{C}-\mathrm{NMR}\left(\mathrm{CDCl}_{3}\right) \delta=43.0,92.3$, 106.3, 112.1, 118.2, 122.0, 124.9, 125.6, 126.7, 129.4, 132.7, 141.2, 153.1, 157.3, 162.9, 163.0 ppm; HRMS (EI) $m / z=315.9971, \mathrm{C}_{16} \mathrm{H}_{9} \mathrm{O}_{3} \mathrm{ClS}$ requires 315.9961 .

\subsection{Synthesis of 8-chloro-3-(2-methoxyphenyl)-2-methyl-furo[3,2-c]chromen-2-one (5b)}

Under nitrogen atmosphere, a pressure-resistant septum-sealed glass vial was charged with 1-(2methoxyphenyl)-2-propyn-1-ol (2b, $0.162 \mathrm{~g}, 1 \mathrm{mmol})$, 6-chloro-4-hydroxychromen-2-one (3, $0.197 \mathrm{~g}$, $1 \mathrm{mmol})$, THF $(0.5 \mathrm{~mL}),\left[\mathrm{Ru}\left(\eta^{3}-2-\mathrm{C}_{3} \mathrm{H}_{4} \mathrm{Me}\right)(\mathrm{CO})(\mathrm{dppf})\right]\left[\mathrm{SbF}_{6}\right](\mathbf{1}, 0.049 \mathrm{~g}, 0.05 \mathrm{mmol}), \mathrm{CF}_{3} \mathrm{CO}_{2} \mathrm{H}$ ( $37 \mu \mathrm{L}, 0.5 \mathrm{mmol}$ ) and a magnetic stirring bar. The vial was then placed inside the cavity of a CEM Discover ${ }^{\circledR}$ S-Class microwave synthesizer and power was held at $300 \mathrm{~W}$ until the desired temperature was reached $\left(100{ }^{\circ} \mathrm{C}\right)$. Microwave power was automatically regulated for the remainder of the experiment $(3 \mathrm{~h})$ to maintain the temperature (monitored by a built-in infrared sensor). Then, the vial was cooled to room temperature, the volatiles removed under vacuum, and the residue purified by flash chromatography (silica gel) using a mixture EtOAc/hexanes (1:20) as eluent to give $\mathbf{5 b}$. Yellow solid (0.214 g, 63\%); m.p. 120-122 ${ }^{\circ} \mathrm{C}$; IR (Nujol) $v=1749(\mathrm{C}=\mathrm{O}) \mathrm{cm}^{-1} ;{ }^{1} \mathrm{H}-\mathrm{NMR}\left(\mathrm{CDCl}_{3}\right) \delta=2.42$ $(\mathrm{s}, 3 \mathrm{H}), 3.82(\mathrm{~s}, 3 \mathrm{H}), 7.01-7.08(\mathrm{~m}, 2 \mathrm{H}), 7.26-7.43(\mathrm{~m}, 4 \mathrm{H}), 7.85(\mathrm{~d}, 1 \mathrm{H}, J=2.5 \mathrm{~Hz}) \mathrm{ppm} ;{ }^{13} \mathrm{C}-\mathrm{NMR}$ $\left(\mathrm{CDCl}_{3}\right) \delta=12.1,55.1,110.6,113.7,116.2,118.0,118.3,119.6,120.0,129.2,129.4,131.0,132.9$, $136.5,150.1,152.5,156.9,162.5,163.0 \mathrm{ppm}$; HRMS (EI) $m / z=340.0496, \mathrm{C}_{19} \mathrm{H}_{13} \mathrm{O}_{4} \mathrm{Cl}$ requires 340.0502 .

\subsection{X-ray Crystal Structure Determination of Compound $\mathbf{4 a}$}

The most relevant crystal and refinement data are collected in Table 1. Data collection was performed on a Oxford Diffraction Xcalibur Nova single crystal diffractometer, using $\mathrm{Cu}-\mathrm{K} \alpha$ radiation. Images were collected at a $65 \mathrm{~mm}$ fixed crystal-to-detector distance using the oscillation method, with $1^{\circ}$ oscillation and a $5 \mathrm{~s}$ exposure time per image. Data collection strategy was calculated with the program CrysAlis Pro CCD [38]. Data reduction and cell refinement were performed with the program CrysAlis Pro RED [38]. An empirical absorption correction was applied using the SCALE3 ABSPACK algorithm as implemented in the program CrysAlis Pro RED [38]. The software package WinGX was used for space group determination, structure solution and refinement [39]. The structure was solved by direct methods using SIR92 [40]. Isotropic least-squares refinement on $F^{2}$ using 
SHELXL97 was performed [41]. During the final stages of the refinements, all the positional parameters and the anisotropic temperature factors of all the non- $\mathrm{H}$ atoms were refined. The coordinates of the $\mathrm{H}$ atoms were found from different Fourier maps and included in a refinement with isotropic parameters. The function minimized was $\left.\left[\sum w F_{\mathrm{O}}{ }^{2}-F_{\mathrm{c}}{ }^{2}\right) / \Sigma w\left(F_{\mathrm{O}}{ }^{2}\right)\right]^{1 / 2}$ where $w=1 /\left[\sigma^{2}\left(F_{\mathrm{O}}{ }^{2}\right)+\right.$ $\left.(\mathrm{a} P)^{2}+\mathrm{b} P\right](\mathrm{a}=0.0902 ; \mathrm{b}=0.0000)$ with $\sigma^{2}\left(F_{\mathrm{O}}{ }^{2}\right)$ from counting statistics and $P=\left(\mathrm{Max}\left(F_{\mathrm{O}}{ }^{2}+\right.\right.$ $\left.2 F_{\mathrm{c}}{ }^{2}\right) / 3$. Atomic scattering factors were taken from the International Tables for X-ray Crystallography [42]. The crystallographic plot was made with PLATON [43].

Table 1. Crystal data and structure refinement parameters for compound $4 \mathbf{a}$.

\begin{tabular}{|l|l|}
\hline Empirical formula & $\mathrm{C}_{19} \mathrm{H}_{13} \mathrm{O}_{4} \mathrm{Cl}$ \\
Formula weight & 340.74 \\
Temperature & $150(2) \mathrm{K}$ \\
Wavelength & $1.5418 \AA$ \\
Crystal system, space group & triclinic, $P-1$ \\
Unit cell dimensions & $a=4.8366(2) \AA \alpha=94.822(4)^{\circ}$ \\
& $b=11.0016(5) \AA \beta=90.363(4)^{\circ}$ \\
& $c=14.6466(7) \AA \gamma=94.200(4)^{\circ}$ \\
Volume & $774.45(6) \AA^{3}$ \\
$Z$, calculated density & $2,1.461 \mathrm{mg} / \mathrm{m}^{3}$ \\
Absorption coefficient & $2.369 \mathrm{~mm}{ }^{-1}$ \\
$F(000)$ & 352 \\
Crystal size & $0.37 \times 0.03 \times 0.02 \mathrm{~mm}$ \\
Theta range for data collection & 3.03 to $73.76^{\circ}$ \\
Limiting indices & $-4 \leq \mathrm{h} \leq 6,-13 \leq \mathrm{k} \leq 12,-17 \leq 1 \leq 17$ \\
Reflections collected $/$ unique & $7403 / 2919\left(R_{\text {int }}=0.0214\right)$ \\
Completeness to theta $=73.76^{\circ}$ & $93.4 \%$ \\
Refinement method & Full-matrix least-squares on $F^{2}$ \\
Data / restrains / parameters & $2919 / 0 / 269$ \\
Goodness-of-fit on $F^{2}$ & 1.166 \\
Final $R$ indices $[I>2$ sigma $(I)]$ & $R_{1}=0.0411, w R_{2}=0.1177$ \\
$R$ indices (all data) & $R_{1}=0.0517, w R_{2}=0.1354$ \\
Largest diff. peak and hole & 0.334 and $-0.267 \mathrm{e} \cdot \AA^{3}$ \\
\hline
\end{tabular}

\section{Conclusions}

In summary, an efficient synthesis of unusual and remarkably stable 2-methylene-2,3dihydrofuro[3,2-c]chromen-2-one derivatives, by coupling of secondary propargylic alcohols with commercially available 6-chloro-4-hydroxychromen-2-one, has been developed with the aid of the catalytic system $\left[\mathrm{Ru}\left(\eta^{3}-2-\mathrm{C}_{3} \mathrm{H}_{4} \mathrm{Me}\right)(\mathrm{CO})(\mathrm{dppf})\right]\left[\mathrm{SbF}_{6}\right] / \mathrm{CF}_{3} \mathrm{CO}_{2} \mathrm{H}$. Apparently, the presence of the electron-withdrawing $\mathrm{Cl}$ substituent on the 4-hydroxychromen-2-one skeleton exerts a marked influence on the behavior of these species since, as previously described by us [21], the same reactions performed with its non-substituted counterpart leads to the selective formation of isomeric furo[3,2$c$ chromen-2-ones by aromatization of the five-membered ring. Overall, the results reported herein 
represent a new example of the utility of the allyl-ruthenium(II) complex $\mathbf{1}$ in synthetic organic chemistry [25].

\section{Acknowledgments}

This work was supported by the Spanish MICINN (Projects CTQ2006-08485/BQU, CSD200700006 and CTQ2010-14796/BQU). N.N. thanks MEC of Spain and the European Social Fund (FPU program) for the award of a $\mathrm{Ph} . \mathrm{D}$. grant.

\section{Conflict of Interest}

The authors declare no conflict of interest.

\section{References and Notes}

1. Sethna, S.M.; Shah, N.M. The chemistry of coumarins. Chem. Rev. 1945, 36, 1-62.

2. Murray, R.D.; Méndez, J.; Brown, S.A. The Natural Coumarins: Occurrence, Chemistry \& Biochemistry; John Wiley \& Sons: New York, NY, USA, 1982.

3. Hoult, J.R.S.; Payá, M. Pharmacological and biochemical actions of simple coumarins: Natural products with therapeutic potential. Gen. Pharmacol. 1996, 27, 713-722.

4. Coumarins: Biology, Applications and Mode of Action; O'Kennedy, R., Thornes, R.D., Eds.; John Wiley \& Sons: Chichester, UK, 1997.

5. Gambari, R.; Lampronti, I.; Bianchi, N.; Zuccato, C.; Viola, G.; Vedaldi, D.; Dall'Acqua, F. Structure and biological activity of furocoumarins. Top. Heterocycl. Chem. 2007, 9, 265-276.

6. Conforti, F.; Marrelli, M.; Menichini, F.; Bonesi, M.; Statti, G.; Provenzano, E.; Menichini, F. Natural and synthetic furanocoumarins as treatment for vitiligo and psoriasis. Curr. Drug Ther. 2009, 4, 38-58.

7. Santana, L.; Uriarte, E.; Roleira, F.; Milhazes, N.; Borges, F. Furocoumarins in medicinal chemistry. Synthesis, applications, and biological activity. Curr. Med. Chem. 2004, 11, 3239-3261.

8. Traven, V.F. New synthetic routes to furocoumarins and their analogs: A review. Molecules 2004, 9, 50-66.

9. Lee, Y.R.; Byun, M.W.; Kim, B.S. Efficient one-step synthesis of 2-arylfurans by ceric ammonium nitrate (CAN)-mediated cycloaddition of 1,3-dicarbonyl compounds to alkynes. Bull. Korean Chem. Soc. 1998, 19, 1080-1083.

10. Kobayashi, K.; Sakashita, K.; Akamatsu, H.; Tanaka, K.; Uchida, M.; Uneda, T.; Kitamura, T.; Morikawa, O.; Konishi, H. CAN-mediated formation of furopyranones and furoquinolinones. Heterocycles 1999, 51, 2881-2892.

11. Lee, Y.R.; Suk, J.Y.; Kim, B.S. Rhodium(II)-catalyzed reactions of 3-diazo-2,4-chromenediones. First one-step synthesis of pterophyllin 2. Tetrahedron Lett. 1999, 40, 6603-6607.

12. Tollari, S.; Palmisano, G.; Cenini, S.; Crovotto, G.; Giovenzana, G.B.; Penoni, A. Synthesis of furocoumarins via rhodium(II)-catalysed heterocyclisation of 3-diazobenzopyran-2,4(3H)-dione with terminal alkynes. Synthesis 2001, 735-740.

13. Cheng, G.; Hu, Y. One-pot synthesis of furocoumarins through cascade addition-cyclizationoxidation. Chem. Commun. 2007, 3285-3287. 
14. Cheng, G.; Hu, Y. Two efficient cascade reactions to synthesize substituted furocoumarins. J. Org. Chem. 2008, 73, 4732-4735.

15. Conreaux, D.; Belot, S.; Desbordes, P.; Monteiro, N.; Balme, G. Et ${ }_{3} N$-Induced demethylationannulation of 3-alkynyl-4-methoxy-2-pyridonas and structurally related compounds in the synthesis of furan-fused heterocycles. J. Org. Chem. 2008, 73, 8619-8622.

16. Raffa, G.; Rusch, M.; Balme, G.; Monteiro, N. A Pd-catalyzed heteroannulation approach to 2,3disubstituted furo[3,2-c]coumarins. Org. Lett. 2009, 11, 5254-5257.

17. Chen, L.; Li, Y.; Xu, M.-H. One-pot synthesis of furocoumarins via sequential Pd/Cu-catalyzed alkynylation and intramolecular hydroalkoxylation. Org. Biomol. Chem. 2010, 8, 3073-3077.

18. Cadierno, V.; Gimeno, J.; Nebra, N. A novel propargylation/cycloisomerization tandem process catalyzed by a ruthenium(II)/trifluoroacetic acid system: One-pot entry to fully substituted furans from readily available secondary propargylic alcohols and 1,3-dicarbonyl compounds. Adv. Synth. Catal. 2007, 349, 382-394.

19. Albers, J.; Cadierno, V.; Crochet, P.; García-Garrido, S.E.; Gimeno, J. Octahedral ruthenium(II) complexes cis, cis- $\left[\mathrm{RuX}_{2}(\mathrm{CNR})(\mathrm{CO})\left(\mathrm{P}^{\wedge} \mathrm{P}\right)\right]$ and cis, cis, cis- $\left[\mathrm{RuX} \mathrm{X}_{2}(\mathrm{CO})_{2}\left(\mathrm{P}^{\wedge} \mathrm{P}\right)\right]\left(\mathrm{X}=\mathrm{Cl}, \mathrm{Br} ; \mathrm{P}^{\wedge} \mathrm{P}=\right.$ 1,1'-bis(diphenylphosphino)ferrocene, 1,1'-bis(diisopropylphosphino)ferrocene): Synthesis and catalytic applications in transfer hydrogenation of acetophenone and cycloisomerization of (Z)-3methylpent-2-en-4-yn-1-ol. J. Organomet. Chem. 2007, 692, 5234-5244.

20. Cadierno, V.; Gimeno, J.; Nebra, N. One-pot three-component catalytic synthesis of fully substituted pyrroles from readily available propargylic alcohols, 1,3-dicarbonyl compounds and primary amines. Chem. Eur. J. 2007, 13, 9973-9981.

21. Cadierno, V.; Díez, J.; Gimeno, J.; Nebra, N. Ruthenium/TFA catalyzed coupling of activated secondary propargylic alcohols with cyclic 1,3-diones: Furan vs. pyran ring formation. J. Org. Chem. 2008, 73, 5852-5858.

22. Cadierno, V.; Crochet, P. Ruthenium-catalyzed furan- and pyrrole-ring formation. Curr. Org. Synth. 2008, 5, 343-364.

23. Cadierno, V.; Gimeno, J.; Nebra, N. One-pot three-component synthesis of tetrasubstituted N-H pyrroles from secondary propargylic alcohols, 1,3-dicarbonyl compounds and tert-butyl carbamate. J. Heterocycl. Chem. 2010, 47, 233-236.

24. García-Garrido, S.E.; Francos, J.; Cadierno, V.; Basset, J.M.; Polshettiwar, V. Chemistry by nanocatalysis: First example of a solid-supported RAPTA complex for organic reactions in aqueous medium. ChemSusChem 2011, 4, 104-111.

25. Cadierno, V.; García-Garrido, S.E.; Gimeno, J.; Nebra, N. Atom-economic transformations of propargylic alcohols catalyzed by the 16-electron allyl-ruthenium(II) complex $\left[\mathrm{Ru}\left(\eta^{3}-2-\right.\right.$ $\left.\left.\mathrm{C}_{3} \mathrm{H}_{4} \mathrm{Me}\right)(\mathrm{CO})(\mathrm{dppf})\right]\left[\mathrm{SbF}_{6}\right]$ (dppf $=1,1^{\prime}$ '-bis(diphenylphosphino)ferrocene). Inorg. Chim. Acta 2010, 363, 1912-1934.

26. Huang, W.; Wang, J.; Shen, Q.; Zhou, X. Yb(OTf) ${ }_{3}$-catalyzed propargylation and allenylation of 1,3-dicarbonyl derivatives with propargylic alcohols: One-pot synthesis of multisubstituted furocoumarin. Tetrahedron 2007, 63, 11636-11643.

27. Microwaves in Organic Synthesis; Loupy, A., Ed.; Wiley-VCH: Weinheim, Germany, 2006.

28. Kappe, C.O.; Dallinger, D.; Murphee, S.S. Practical Microwave Synthesis for Organic Chemists; Wiley-VCH: Weinheim, Germany, 2009. 
29. Microwave Heating as a Tool for Sustainable Chemistry; Leadbeater, N.E., Ed.; CRC Press: Boca Raton, FL, USA, 2011.

30. Sawhney, K.N.; Mathur, K.B.L. Studies on some structural aspects of 4-hydroxycoumarin: Further extension of Meerwein's diazo reaction and a substitution reaction involving 2-chloro-2methylbut-yne. Indian J. Chem. B: Org. Chem. 1976, 14, 518-521.

31. Chênevert, R.; Pagé, J.; Plante, R.; Beaucage, D. Synthesis of 4,4-dimethyl-5-methylene-4,5dihydrofurans. Synthesis 1982, 75-77.

32. Chênevert, R.; Pagé, J.; Voyer, N. Synthesis of ( \pm )-dehydroxyglaupalol and analogs. Synth. Commun. 1984, 14, 737-742.

33. Reisch, J.; Dharmaratne, H.R.W. A convenient synthesis of the 2-dimethyl-2H-chromene system. Z. Naturforsch. B 1985, 40, 636-638.

34. Mitra, J.; Mitra, A.K. Palladium(II) assisted cyclization of hydroxyallylcoumarins. Indian J. Chem. B: Org. Chem. 1994, 33, 276-279.

35. Berger, S.; Haak, E. Ruthenium-catalyzed addition of carboxylic acids or cyclic 1,3-dicarbonyl compounds to propargylic alcohols. Tetrahedron Lett. 2010, 51, 6630-6634.

36. Cadierno, V.; Díez, J.; García-Garrido, S.E.; Gimeno, J. [Ru( $\left.\left.\eta^{3}-2-\mathrm{C}_{3} \mathrm{H}_{4} \mathrm{Me}\right)(\mathrm{CO})(\mathrm{dppf})\right]\left[\mathrm{SbF}_{6}\right]$ : A mononuclear $16 \mathrm{e}^{-}$ruthenium(II) catalyst for propargylic substitution and isomerization of $\mathrm{HCCCPh}_{2}(\mathrm{OH})$. Chem. Commun. 2004, 2716-2717.

37. Midland, M.M. Preparation of monolithium acetylide in tetrahydrofuran. Reaction with aldehydes and ketones. J. Org. Chem. 1975, 40, 2250-2252.

38. CrysAlis ${ }^{\text {Pro }}$ CCD \& CrysAlis ${ }^{\text {Pro }}$ RED; Oxford Diffraction Ltd.: Oxford, UK, 2008.

39. Farrugia, L.J. Win $G X$ suite for small-molecule single-crystal crystallography. J. Appl. Crystallogr. 1999, 32, 837-838.

40. Altomare, A.; Cascarano, G.; Giacovazzo, C.; Guagliardi, A. Completion and refinement of crystal structures with SIR92. J. Appl. Crystallogr. 1993, 26, 343-350.

41. Sheldrick, G.M. SHELXL97: Program for the Refinement of Crystal Structures; University of Göttingen: Göttingen, Germany, 1997.

42. International Tables for X-Ray Crystallography; Kynoch Press: Birminghan, UK, 1974, Volume IV (present distributor: Kluwer Academic Publishers: Dordrecht, The Netherlands).

43. Spek, A.L. PLATON: A multipurpose Crystallographic Tool; University of Utrecht: Utrecht, The Netherlands, 2006.

Sample Availability: Samples of the compounds $\mathbf{4 a - d}$ and $\mathbf{5 b}$ are available from the authors.

(C) 2011 by the authors; licensee MDPI, Basel, Switzerland. This article is an open access article distributed under the terms and conditions of the Creative Commons Attribution license (http://creativecommons.org/licenses/by/3.0/). 